\title{
MEDIA LITERACY EDUCATION FOR DIVERSE SOCIETIES
}

Annamária Neag, Çiğdem Bozdağ and Koen Leurs

\section{Summary}

Since the 1980s, media literacy became a central topic in the field of communication, media and education studies, as a result of a parallel growth of polarization between societal groups and use of digital technologies for self-representation. In this article, we present a brief overview of the evolvement of media literacy and other competing terms and discuss emerging approaches that incorporate issues related to the politics of difference, representations and voice of marginalised groups. Although existing concepts and projects focus on singular aspects such as representation and media production by minorities, they do not commonly integrate concerns of diversity and media literacy education from a critical and holistic perspective. Building on critical pedagogy, feminist and decolonial theory, we argue that there is a need for a more inclusive and intersectional approach to media literacy education. Such an approach should not only focus on marginalised groups, but society as a whole; it should advocate a critical understanding of the mediated construction of reality and offer grounds to successfully challenge dominant representations; it should not only equip people with the skills to participate and raise their own voices, but also pay more attention to practices of listening to work towards a level playing field between mainstream and marginalized groups.

Keywords (5-10): media literacy; media education; diversity; inclusion; intercultural dialogue; media representations; difference; critical pedagogy; race and ethnicity communication; civic media; civic media literacy

\section{Introduction}

Over the course of the previous four decades, media literacy has become a widely discussed - and contested - topic among teachers, academics and other professionals interested in promoting understanding of the roles media play in society. Over time, media literacy education has taken many forms, ranging from elective to core-curriculum activities, train-the-trainer sessions, government campaigns to smartphone apps. However, it has to be noted that no consensus exists about conceptualisations, operationalisations or aims of media literacy. The terminologies and definitions have changed over time, as various stakeholders have engaged with media literacy. As a result, different approaches now co-exist, incorporating a variety of perspectives (Koltay, 2011). The gap between the two foundations of media literacy education (media studies and media education) has not yet been closed, with many debates still going on between those representing theory-driven scholarship and those who argue for the practice of media education (for an in-depth discussion, see Friesem \& Friesem, 2019).

Only more recently, media literacy literature started paying attention to differences related to race, ethnicity, gender, sexuality, class and ability. Diversity in the media and social inclusion of marginalised groups are often considered in Eurocentric frameworks of hate speech and intercultural dialogue. Even when minorities or other marginalized groups are targeted in policy papers and projects related to media literacy, minority subjects are commonly 'absorbed' within 
undifferentiated categories of "sexual minorities", "migrants" or "refugees". This leads to further othering and homogenisation of these groups lacking recognition of their distinct histories and experiences of exclusion in society and in the media more particularly. As a result, a specific racialised, heteronormative, able-body oriented order is maintained. Not enough attention is paid to also to how non-normative bodies are implicated in the established communication order that gives voice to some and silences others: "Not everyone speaks and is heard in the same way; not everyone is equally represented" (Georgiou, 2018, p. 49).

Although attention for the politics of difference, inclusion and intercultural dialogue were among the goals of media literacy education, these were not central to the practice of media literacy education until very recently. Therefore, article's aim is to discuss whether existing definitions and approaches hold potential to advance a multiplicity of voices in the public arena, for example, by offering media production workshops for minorities, migrants and refugees. The article first provides an overview of key concepts of media literacy in relation to diversity, their interpretations and genealogies. Secondly, it discusses emergent forms of inclusive media literacy education research and practices. Seeking to connect emergent practice with theory, in the final section, it proposes a comprehensive framework for an intercultural understanding of critical media literacy education.

\section{Media Literacy: The Many Faces of a Concept}

The idea of media literacy championing critical and proactive media subjects, consumers and/or user comes in many shapes and forms. While some academics use the term 'digital literacy' or 'multiple literacies' (Kellner, 1998; Livingstone, 2004; Kalmus et al., 2009; Plester \& Wood, 2009), others argue for the use of 'information literacy' (Zurkowsky, 1974; Bundy, 2004). UNESCO, on the other hand, promotes media and information literacy, or MIL (UNESCO, 2013). These concepts are all interconnected, albeit they focus on slightly different aspects at times. Moreover, as we will make apparent below the various conceptualizations of media literacy are deeply situated and reflect commitments of various media literacy stakeholders.

A common umbrella definition of media literacy comes from Ofcom, the UK's communications regulator. Ofcom sees media literacy as "the ability to access, understand and create communications in a variety of contexts" (Ofcom, 2006). The Ofcom definition is based on an earlier US definition, from the Aspen Institute Report of the National Leadership Conference on Media Literacy:

A media literate person - and everyone should have the opportunity to become one can access, analyze, evaluate, and produce both print and electronic media. The fundamental objective of media literacy is critical autonomy relationship to all media. Emphases in media literacy training range widely, including informed citizenship, aesthetic appreciation and expression, social advocacy, self-esteem, and consumer competence (Aufderheide, 1992).

The importance of social advocacy, for the benefit of everyone, occupies a central tenet in this early definition. However, this influential definition is also limited as it does not address explicitly issues related to social justice or how differences and inequalities related to race, ethnicity, gender, socioeconomic background and ability influence media literacy. 
The European Commission has also become a prominent actor in shaping policies regarding media literacy education. Media literacy as a term first appeared in the European Audiovisual Services Directive (AVMSD) in 2007. The AVMSD was recently revised and now the Member States of the European Union are required to promote and support citizens in becoming media literate (European Commission, n.d.). The focus of the EC's definition today seems to be on countering disinformation and fake news as well as providing ways for publics to be able to take informed decisions. Although empowerment is included as an aim, it is not made explicit how media literacy can help in tackling discrimination or fostering intercultural dialogue. Parallel to the EC, the United Nations is an important actor in international media literacy policy. Besides emphasizing opportunities and risks, they are particularly concerned with empowering children as equal participants in the digital world. For instance, the UN Committee on the Rights of the Child' have recently adopted General Comment No. 25 on children's rights in relation to the digital environment which was drafted by academics, NGOs and professionals (CRC, 2021).

In his overview, David Buckingham (2009, p. 14) observed that in all the different definitions "one can find a vast range of ideas about what media literacy is". Interpretations range from developing technical skills to protecting children and the elderly and fostering cultural participation, agency and empowerment. Some critics argue that audiences (including children) can be media literate without any special education (Warschauer, 2001), and that the public can have "[...] a critical eye on understanding" (Gauntlett, 2007, p. 3) the techniques used by the media. Buckingham (2009, p. 10) argues that audiences can indeed be active and critical, but he notes that there are certain topics (such as the media industries or the uses and implications of media within society) that need to be taught. This point is extremely important when it comes to recognizing the efforts that are required in order to champion media literacy for intercultural dialogue. Scholars argue that only through structural investments and engagements "media and digital literacy play a critical role towards an inclusive society" (Simões \& Santos, 2020, p. 6529). Learning about how media representations of marginalised groups reinforce stereotypes is just one of the many topics media literacy programs can cover.

Going forward, digital literacy has become a popular term, replacing buzzword predecessors including network literacy (McClure, 1994), social media literacy, or Internet literacy (Martin, 1997). Gilster (1997, p. 5) defined digital literacy as "literacy in the Digital Age". Today young people engage with media not as technologies, but as cultural forms (Buckingham, 2006). Therefore, digital literacy should not be seen in a functional way (e.g. if one has the ability to operate with ICTs) because evaluation, critical thinking and media production are overall important and required competencies to participate in today's society (Buckingham, 2006). Discussions on "algorithmic" and "data literacy" are also emerging. Media literacy thinkers recognize these as rhetorically powerful to address the transition from print to digital media environments. They however remain hesitant in their embrace as these approaches remain conceptually underdeveloped (Pangrazio \& Sefton-Green, 2020).

Another popular term is information literacy, a concept defined by the American Library Association as "[...] a set of skills needed to find, retrieve, analyze and use information" (American Library Association, n.d.). In parallel to digital literacy, the advocates of this term highlight the importance of knowing how to find your way in the wealth of information available on- and off-line: 
[...] The information literate person, therefore, is empowered for effective decision making, freedom of choice, and full participation in a democratic society. (Breivik, Hancock, \& Senn, 1998)

The supporters of this term talk about the commitment of librarians to further the inclusion of all social groups through knowledge equity. This specific focus on equity is very important when it comes to issues of addressing racism, discrimination or the digital divide. For example, in light of refugee information practices, Melissa Wall (2019) and colleagues point at the "information precarity", experienced among forced migrants while being displaced, in refugee camps and during settlement. The concept alerts us to "the condition of instability that refugees experience in accessing news and personal information, potentially leaving them vulnerable to misinformation, stereotyping, and rumors that can affect their economic and social capital" (Wall et al., 2019, p. 240). Participation in democracy is not possible without being able to navigate the information landscape and without the skills to make one's voice heard.

Media and information literacy (MIL) is a "pedagogical approach that takes into consideration the new cultures emerging from the Information Society" (UNESCO, n.d.). According to UNESCO, media and information literacy is an overarching term that includes digital, ICT, information and media literacy (UNESCO, 2013). The authors emphasize the various types of literacies overlap in a number of characteristics, such as their object of interest or their interdisciplinary approach. MIL approaches share a human rights-based approach and an emphasis on critical and reflective thinking as well as a cultivation of competencies. UNESCO also notes that these different types of literacies have an impact on people's personal, social and professional lives (UNESCO, 2013). The organization advocates for the improvement of media and information literacy as a means to further empowerment. According to UNESCO experts, media and communication can help in assisting:

[...] sustainable development by enabling people to take control over their own livelihood by identifying their needs and problems and by providing access to knowledge and information to enable informed choices: to use communication for change. (Jacquinot-Delaunay, Carlsson, Tayie \& Perez Tornero, 2008)

In a similar fashion, Douglas Kellner (1998, p. 118) introduced multiple literacies, as a means of empowering citizens: "In addition to critical media literacy, print literacy, computer literacy, and multimedia literacy [...], multiple literacies involve cultural literacy, social literacy, and ecoliteracy." He believes that multiple literacies are essential for creating a more just society and a fuller democratic participation (Kellner, 1998). In a later article, Kellner and Share (2007) define critical media literacy as an encompassing broader term that "[...] expands literacy to include information literacy, technical literacy, multimodal literacy, and other attempts to broaden print literacy concepts to include different tools and modes of communicating" (p. 61).

In a similar vein, a more contemporary rendering of critical media literacy comes from Mihailidis (2018), who argues for the development of civic media literacies "[...] that reframe media literacy interventions towards civic intentionality" (p. 2). Mihailidis (2019) believes that these literacies should be based on the value systems of agency, caring, persistence, critical consciousness and emancipation. In his view, by adding civic intentionality to media literacies, interventions can be designed to bring people together for solving social problems and create a positive dialogue (Mihailidis, 2018). 
For scholars studying the role of media in diverse societies, it seems that it is a matter of choice among academic traditions to decide between the often overlapping and competing terms. However, it should be noted that these definitions and rationales have not emerged from a void. For example, all the concepts discussed above share a view of media literacy that is rooted in structures and production of knowledge that assume a universality of socio-cultural and educational experiences in the Global North. Critical reflection is needed, however, to understand if and how these conceptualizations can be relevant to other societies for which "the West speaks" or indeed to racialized and otherwise marginalized groups living in Western countries. Jad Melki (2018) argues that outside the Global North there is a dire need for a different type of media literacy, which he calls - influenced by Paulo Freire's work - the "media literacy of the oppressed". For Melki (2018, p. 6):

A media literacy of the oppressed reframes existing concepts and competencies, engages local communities in the reinvention of media literacy. [...] It critiques and simultaneously borrows from the external. It roots itself in the local without being blind to indigenous problems. It struggles for freedom and social justice at the level of the local as well as the global.

Melki (2018) also mentions that this is not unique to developing countries; minority and marginalized groups in Western countries face similar obstacles and issues when it comes to media literacy education. In this vein then, Marketa Zezulkova and Annamária Neag (2019) contend that media literacy education should take into consideration the specifics of a given social, cultural and learning context and start from the real needs, experiences and wants of the people whom these programs want to address. For example, although the understanding of media literacy in Chinese societies (China, Taiwan and Hong Kong) was greatly influenced by Western thought (Lee, 2021), policies and approaches are driven by a revolutionary development of ICT and a utilitarian approach to gaining technical skills, rather than a more complex set of critical and creative abilities.

To understand the modes operandi of the various schools of thought outlined, Sonia Livingstone et al (2008) argue that one should always focus on the question of purpose: so what is the purpose of media literacy, digital literacy or MIL? Livingstone and her colleagues (2008, $\mathrm{p}$. 18) suggest that there are three broad purposes to which these literacies might contribute: 1) democracy, participation and active citizenship; 2) knowledge economy, competitiveness and choice and 3) lifelong learning, cultural expression and personal fulfillment. In this chapter, we posit that intercultural media literacy education for diverse societies encompasses each of these three purposes, even if relevant literature only addresses it as a secondary or marginal dimension of literacy's desired consequences.

The discussion of field-setting literature above shows that attention to the politics of difference and inclusion to some degree has always been embedded into various media literacy frameworks. However, this attention has mostly remained implicit, and as a result media literacy practices do not engage with these themes by default. Commonly used terms such as criticality, empowerment, sustainable development and equity indirectly point to the role of inclusion/exclusion mechanisms in cultural politics, power and economics, however these relationships have remained undertheorized. Because we agree that media literacy education does not automatically lead to an "increased cultural understanding" (Zezulkova and Neag, 2019, p. 7), a more explicit consideration and theorization of the situated politics of difference and alterity in 
relation to media literacy is urgently needed. Below, we will offer conceptual orientations, drawing from emerging media literacy education programs and practices with a focus on diversity.

\section{Emerging Approaches and Practices}

Having charted evolving understandings of media literacy, this section reviews emerging practices that focus on issues related to representation and diversity, in particular programs and research that involve disadvantaged and/or marginalized groups including women, LGBTIQ+ folk, disabled people, migrants and refugees. We will, firstly, discuss how emerging literature integrates issues related to media representations, diversity and cultural difference into media literacy education. The development of intercultural competence and dialogue is perceived as one of the aims of media literacy education in this body of research. Secondly, we will focus on media education and media literacy projects specifically aimed at underserved, vulnerablised and marginalised groups.

A critical approach to media literacy as described in the previous section should consider how media contributes to the reproduction of existing inequalities, stereotypes, forms of discrimination, racism, sexism, ableism, nationalism, heteronormativity among other issues. Adopting a critical approach, Kellner and Share (2007) argue that media education should question the workings of representation to engage with issues of ideology, power, and pleasure (Kellner and Share, 2007, p. 65). Furthermore, they propose that media literacy should challenge the politics of representation in the media in relation to gender, race and class. Several studies on media representations of refugees demonstrate, for example, how migrants, refugees and minorities are often underrepresented in media or often portrayed as threats, criminals or powerless victims not only on mass media (Chouliaraki and Zaborowski, 2017; Van Gorp, 2005), but also on social media (Bozdağ, 2020; Siapera et al., 2018). Through the images and representations that they disseminate, today's mass media and digital media environments also serve as amplifiers of violence, polarization, discrimination, nationalism and racism and also contribute to the rise of extreme right-wing movements (Raineri, 2019, p. 10). Mediated communication today is not only a major source for understanding and interpreting the world around us, but also provides an essential framework for mediating and fostering dialogue and exchange among cultures (Waheed Khan, 2008, p. 15). A critical media literacy education could contribute to critical awareness about the exclusionary workings of media discourses to achieve greater tolerance and equity (Raineri, 2019).

In recent years, intercultural dialogue is promoted as a way to combat increasing mediated polarization. With this aim, UNESCO champions Media and Information Literacy "as an essential tool to facilitate intercultural dialogue, mutual understanding and a cultural understanding of people" (Wilson et al., 2014, p. 20). In a report issued by the European Commission, "intercultural dialogue" is foregrounded as a principal means of "challenging radicalisation and hate speech". For this purpose, it is included in the list of five main skills related to media literacy (alongside media use, critical thinking, creativity and participation and interaction, see Chapman, 2016, p. 62). Based on an analysis involving questionnaires distributed among a large group of media literacy stakeholders from civil society, public authorities and academia, Chapman (2016) reviewed media literacy policies and projects in $28 \mathrm{EU}$ countries. Importantly, the report shows that intercultural dialogue is the least addressed skill among the five major skills considered part of media literacy. 
In the following, we will present a selection of media literacy projects and research that deal with the topics relevant to intercultural dialogue and promoting inclusive media and understanding in diverse societies.

\section{Media Literacy Education Against Hate Speech and Discrimination}

In recent years, several practical projects were initiated with a focus developing media literacy education to tackle hate speech and discrimination online. These projects address both media professionals, who produce these representations, and also target audiences of these representations that aim to raising a critical awareness about how media outlets construct stereotypical renderings of marginalised groups. One example is the Europe-wide \#MediaAgainstHate ${ }^{1}$ campaign that is organized by the European Federation of Journalists. The project targets media and journalists and aims to have a "balanced and fair media reporting" of refugees and migrants by offering additional training and resources for media professionals and media organisations. Another example is the MediaSmarts ${ }^{2}$ initiative, a center in Canada that focuses on digital and media literacy. The center provides information and resources for teachers focusing on media issues such as body images, gender representations and diversity in the media and digital issues such as online hate, cyberbullying and online ethics. The diversity section of their website includes materials and guidelines for teachers focusing on specific examples of media representations that are relevant in the Canadian context, for example common and stereotypical representations of Aboriginal people, portrayals of visible minorities, people with disabilities, queer people or media portrayals of different religions.

\section{Media Literacy Education for Deconstructing Representations}

Hate speech is an outcome of exclusionary, discriminating and biased views towards "others" including migrants, refugees and minorities (Titley, 2020), whose understanding of "reality" is constructed in particular ways through media representations. In order to truly understand the roots of hate speech and discrimination in media, media literacy projects aim to adopt a broader and critical perspective towards the ways media constructs certain worldviews and leads to misrepresentation of certain groups such as refugees and migrants. Only if we develop a critical perspective towards media discourses as social constructions through media education, we can deal with hate speech that is the outcome of such exclusionary, discriminating and biased worldviews that are represented as the objective reality through the media. Adopting an intercultural approach, critical media literacy education can provide tools to promote the development of a critical understanding of how media representations are always social constructs, reflecting particular perspectives, interests and historical legacies. MEET (Media Education for Equity and Tolerance) is one of the more comprehensive projects that was supported by European Commission (realized in Italy, Austria, Germany, Belgium and Slovenia). MEET focuses on disadvantaged young people and aims to promote inclusive and democratic citizenship and intercultural education through media education to fight against discrimination and intolerance through action research (Raineri, 2019, p. 11). One of the outcomes of the project that was co-developed and tested with participating teachers and students was an open access online toolkit with videos, pedagogical guidelines and learning scenarios for teachers ${ }^{3}$. The learning scenarios and the videos propose teaching practices related to development 
of critical analytic skills about media representations such as recognizing misinformation about different groups, recognizing propaganda or sponsored content and also media production skills for example by producing alternative representations to the analyzed media texts.

An interesting and novel approach against biased media representations are the digital selfrepresentations created by social media influencers with a migration background. Some of these vloggers have a large following (e.g. Syrian vlogger Mahmoud Bitar living in Sweden had 1.7 million subscribers on YouTube at the time of writing), and they discuss the everyday challenges of being a foreigner in a new country. In Finland, under the hashtag \#ennenolinpakolainen (Once, I was a refugee) former refugees engaged in a social media campaign to counter views of refugees as economic burdens and noncitizens (Nikunen, 2019). Recognizing that community leaders have a strong following on social media, the International Office of Migration (IOM), started a campaign called \#IamaMigrant (iamamigrant.org). In this campaign, migrant YouTubers share their migration experiences with non-migrants which could be beneficial to combat negative discourses. Examples show these blogs and vlogs could be important new ways to fight hate speech and negative media representations, as they allow migrant makers to level with fellow audiences. However, the question also emerges how IOM curates the stories presented on their website. In videos addressed at future migrants, the emphasis on danger and risk also shows how migrant media makers are co-opted in institutionalized migration deterrence campaigns (e.g. Musarò, 2019).

\section{Media Literacy Education for Intercultural Dialogue}

Besides media literacy and MIL projects that include intercultural dialogue in their framework, especially in the field of language education, there is also a large body of research that focuses on intercultural learning and dialogue through digital media technologies. For example, there are several projects that look at how digital media technologies can be used for online intercultural exchange projects that are aimed to contribute to intercultural dialogue (Bozdağ, 2018; O'Dowd and Lewis, 2016). Although these projects do not specifically focus on media education as a separate subject in the curriculum, they present good examples of how media education and an intercultural approach may be integrated in other educational subjects. Intercultural email exchange (IEE) projects provide best practices of how digital channels may be embraced for such purposes. See for example an early IEE project between Japanese and Thai students documented by Matthew Rooks (2008). The eTwinning network ${ }^{4}$ is a more recent example, which is built around an online platform for European teachers to connect with other teachers and schools in order to develop joint online projects. Fostering intercultural dialogue among teachers and students and improving their digital literacy is one of the aims of the eTwinning platform.

There are also similar projects that focus on specific marginalized communities such as "the three dollar bill cinema" ${ }^{5}$ " project that focuses on films by, for, and about lesbian, gay, bisexual, transgender, and queer (LGBTQ+) people and their families. The organization aims to foster community engagement through cinema, create educational experiences through films and social dialogue. The three dollar bill cinema is based in the US and for example organize the Seattle transgender film festival as well as the youth workshop "Reel Queer Youth" for video production and media literacy training for LGBT+ youth and their allies. 
Rising Voices is an initiative of the organisation "Global Voices" that aims to promote the inclusion of marginalised communities around the world. Their media literacy project works with indigenous communities in Latin America through digital skills training and mentoring (DW, 2019). Through this program, they support local communities in showcasing their culture and language through online tools. They also invite members of local communities to analyse the media representation of their local issues. With the global proliferation of digital technologies and more affordable Internet access, media education can successfully be used for connecting groups that otherwise would not be familiar with each other and thus strengthening an intercultural dialogue.

\section{Media Literacy Education for Disadvantaged Groups}

Besides the larger body of research and projects that focuses on representations and intercultural dialogue in the field of media literacy education, there are few projects oriented specifically towards the media literacy skills of migrants, refugees and minorities and other marginalized groups (see for example Leurs et al., 2018; Ranieri, 2019; Bruinenberg et al., 2019). 'Children in Communication about Migration (CHICAM)' was a pioneering project, which specially focused on "the social and cultural worlds of refugee and immigrant children". Carried out between 20012004 in 6 European countries, it aimed to promote the inclusion of young refugees and immigrants through action research focused on media production practices. The project was realized through CHICAM clubs that offered extra-curricular media education to migrant children. The attending children learned to produce videos in order to represent issues that they found relevant in their new life context. The project did not only aim to amplify the voices of involved children and help them cope with the challenges of settling in a new context through video production. But the produced videos were also circulated in the CHICAM clubs in different countries to create an intercultural dialogue between the involved children. Similarly, Leurs et al. in their 'Critical Media Literacy through Making Media (MMM)' project co-created a teaching framework in International Transition Classes with refugee children and their language teachers in the Netherlands (see also Bruinenberg et al., 2019). The project seeks to recognize the literacies inherent to media practices required to live through civil war, repression as well as resettlement combined with smart phone media productions (Leurs et al., 2018, p. 430). Another European project that is realized in the Netherlands, Greece, Hungary, Italy and France is "Speak Up! Media for inclusion"." The project aims to offer media and information literacy training to newly arrived migrant and refugee children with a focus on media production skills (radio and film-making) to help them "feel at home quickly and prepare for a future in the host country". Recognizing the importance of an inclusive framework for media literacy, the European Commission has launched a 4-year program entitled Media Literacy for All in 2016 supporting different projects that aim to analyze and foster media literacy of different populations in the $\mathrm{EU}^{8}$. Similarly, in an effort to highlight the demand for more diverse media literacy education programmes, Subervi-Vélez and Cantrell Rosas-Moreno (2020) show that there is a dire need for robust efforts to be directed towards Latino populations in the USA. While there have been a couple of projects (e.g. the translations of Cyberwise's ${ }^{9}$ parental guide and other documents into Spanish), the authors argue that Latino-oriented media literacy programmes are imperative in order to enhance critical thinking and action within this population also (Subervi-Vélez and Cantrell Rosas-Moreno, 2020). 
Ideosync Media Combine ${ }^{10}$ is an Indian media and communication organisation that offers community radios to disadvantaged groups in the country. Beyond this work, they also created the Freedom Community Media School in the informal settlements outside Delhi, where they deliver media literacy programs. This program offers disadvantaged people the possibility of learning digital skills and training to become community reporters and to share their everyday struggles through digital means (MILEN, 2020). Defindia (Digital Empowerment Foundation ${ }^{11}$ ) is another initiative from India that aims to "empower marginalized communities in information dark regions" by providing access to digital media and basic digital skills for people living in rural parts of India.

Rising voices ${ }^{12}$ is another project that aims to use participatory media tools and media education for empowering different communities worldwide especially with a focus on indigenous and endangered languages. The initiative provides resources, microgrant funding, and mentoring to local underrepresented communities for telling their own digital stories using digital media. The initiative supports projects in different countries and continents including Chile, Bolivia, Venezuela, Niger, Uganda, Pakistan, Cambodia, USA among others. Some other examples of media literacy education projects that aim to empower different marginalized groups by offering digital media education workshops and materials are Diraya in the Middle-East and North Africa region $^{13}$, Pyalara ${ }^{14}$ from Palestine and the Cambodian Center for Independent Media. ${ }^{15}$

These projects aim to foster democratic participation of different disadvantaged groups around the world and giving them a voice. In this regard, these projects overlap with the aims of citizenship education that aims to empower different groups in the society to foster civic engagement and political participation among different groups in the society. Besides the issue of empowerment and use of digital media for disadvantaged and marginalized groups for selfrepresentation purposes, several media education projects aim for market integration and professional development of different groups. Some examples include the social enterprises such as the Toti Diversidade para inovação (Diversity for innovation) project in Brazil that aims to train underserved communities through coding and programming. We see the proliferation of similar coding schools across the globe that only focus on specific ICT-skills and seek to empower a specific neoliberal, tech-savvy, flexible type of subject (targeting refugees and other groups) with the promise of market integration.

\section{Intercultural Media Literacy as Critical Pedagogy}

To conclude, we would like to offer contours for a future-oriented intercultural media literacy education, drawing from several strands of critical theory and pedagogy. Accountability and selfreflexivity are pivotal to begin to realize who has the power of definition and means to media literacy initiate projects (Dussel and Dahya, 2017): indeed, we should ask who is in need of a voice? Who is entitled to give voice? Who benefits from these projects that focus on giving voice to particular groups and individuals? Who is involved in knowledge production? How are voices shaped by cultural and institutional constraints? "How do we define and refine the tone, pressures, and expectations associated with particular media forms" (Dahya, 2017, p. 108) when such projects engage particular groups with digital media production? Furthermore, many projects in the field of media literacy education focus on individual agency. Like in many other empowerment initiatives the transformation of individuals' behaviors is prioritized, but questions remain on the broader impact on structural problems and systemic inequalities (McLaughlin, 2016, p. 124). In 
this regard, we also need to question the structural mechanisms that exclude voices of marginalised people from the public sphere.

First, drawing on black feminist theory we argue that a critical approach to media literacy education needs to address diversity and differences through an intersectional lens. Secondly, after having realized media literacy has not emerged from a void, we take cues from Afrofuturism and decolonial theory to articulate and embrace alternative imaginaries of media literacy.

To do justice to the complexities of our multicultural societies, media literacy should ensure the inclusion of a diversity of voices for example through participatory action research. Learners should be equipped with reflective tools in diverse teams; for this purpose, discussions are needed to establish for example 1) community-based parameters for safe encounters; 2) nonoppressive and inclusive language prompts; 3) privilege and gender equity checklists; 4) crosscultural interviewing best practices (e.g. through making intercultural podcasts); 5) meaningful scripting and storyboarding videos with photos and videos from personal archives. This is not easy. These are examples that will demand emotional investment and commitment, which are much needed to learn how to live with difference. To promote media justice, intercultural media literacy should acknowledge and provide practical means to transform how identities and power are shaped through the mediation of intersecting axes of difference including nationality, race, ethnicity, gender, sexuality, religion, ability and socioeconomic class. As our above overview of emerging projects shows, media literacy projects that engage with diversity commonly take single-axes approaches.

As a result, a wealth of critical energy is invested to scrutinize the workings of a singular category of identification and subordination such as race, ethnicity, gender, ability or socioeconomic background. Many of these initiatives offer important insights, but they largely operate in parallel and in isolation from each other. Alongside emerging initiatives around migration, scholars have, for example, prioritized gender/sexuality in other standalone projects: Funk (2018), drawing from critical media literacy, developed the trans*+ media literacy framework in order to help both students and educators to move beyond binary gender representations needed to create "gender expansive and inclusive spaces" (Funk, 2018, p. 216). Scholars have foregrounded race; Tara J. Yosso drew on critical race theory to conceptualize "critical race media literacy" as a means to challenge dominant deficit discourse about Chicano/a/x communities (2002, p. 52), while Yonty Friesem in his call to action to advance "media literacy skills of all" has foregrounded the importance of acknowledging disability theory (2017, p. 12). Charlotte Cooper finally, embraces critical media literacy as an avenue to counter mediated body shaming and fat-phobia (2010). An intersectional reconsideration may offer means for a systematic synthesis of these critical media literacy approaches. Separately, these are all valuable on themselves, but their impact might become substantiated further through cross-fertilization.

Kimberlé Crenshaw (1989) coined the term intersectionality to capture Black women's multiple forms of oppression through the following metaphor: "Consider an analogy to traffic in an intersection, coming and going in all four directions. Discrimination, like traffic through an intersection, may flow in one direction, and it may flow in another" (1989, p. 149). Marie Matsuda (1991) offers useful means for further operationalizing intersectionality in stating:

The way I try to understand the interconnection of all forms of subordination is through a method I call 'ask the other question.' When I see something that looks racist, I ask, 
'Where is the patriarchy in this?' When I see something that looks sexist, I ask, 'Where is the heterosexism in this?' When I see something that looks homophobic, I ask, 'Where are the class interests in this?' (1991, p. 1189).

An intersectional approach to intercultural media literacy seeks to advance critical consciousness about how identity, subordination, cross-group prejudices or within-group prejudices result from intersecting inclusion and exclusion mechanisms that co-shape one another. In our era of social media polarization, exclusionary algorithms, and global hashtagged protests, intersectional critical media literacies may draw attention to how anti-black racism circulating on social media may be co-shaped in a complex interrelationship with patriarchy, white supremacy, classism, sexism, heterosexism, able bodiedness, transphobia or homophobia. This is also a long overdue conceptual move, "Specifically in the context of an intersectional analysis, concerns are largely under examined in the multiple fields that embrace the study of the Internet" (Noble \& Tynes, 2016, p. 4).

With their "intersectional Media Equity Index", Sasha Costanza-Chock (2018) offers a speculative metric operationalizing such an approach. Through working with the following indicators teachers, students and researchers can equip themselves with means to acknowledge and oppose the workings of the intersectional matrix of oppression based on gender, sexuality, race, nationality, ability, among others: "media ownership (who owns the media), employment in media firms (who works in the media), content production (who makes the media), standing (who gets to speak in the media), and attention (who gets listened to)" (Costanza-Chock, 2018, p. 208). While this approach opens up new lines of enquiry and reflection, it also raises questions, for example about the establishment of identity categories (from the community or institutions) and what forms of "communication reparations" could look like (ibid).

In conjunction with a fundamental embrace of intersectionality, the global, and intensely mediated \#BlackLivesMatter human rights movement as well as the scholarly \#communicationsowhite (Chakravartty, Kuo, Grubbs \& McIlwain 2019) intervention point to urgent need to decentre and decolonize media literacy. This is long overdue, as is evidenced by Paula Chakravartty and colleagues' large-scale study of the publication and communication practices of the field of communication, which demonstrated for example a striking "absence of non-White scholars from the canon of communication across all subfields" (2018, p. 255). In parallel, critical scrutiny of information literacy work reveals "the existing information system mirrors the larger social and political order, which is characterized by a radically asymmetrical distribution of power, and is shot through, systematically and structurally, by racism, sexism, homophobia, militarism, and class oppression" (Beilin, 2015). Therefore, in coming to terms with the distinct situatedness of hegemonic media literacy ideas, reflection is needed on the implications of their normative groundedness in Western, capitalist conceptions and assumptions around human rights, free press, autonomy, freedom of speech and liberalism, but also lingering forms of coloniality, white supremacy and other epistemological hegemonies. Learning how to scrutinize and resist dominant regimes of knowledge in theory and praxis is a challenging, but necessary step forward. Below we discuss several critical pedagogies that through their alternative imaginaries could facilitate necessary transformations.

In the wake of the \#BlackLiveMatters movement Michelle M.P. Grue argues Afrofuturism offers important critical anti-racist and intersectional pedagogies for literacy learning: 


\begin{abstract}
Afrofuturism is a storytelling genre that appears in multiple media types, including books, films, television, comics, music, and art. Drawing from genres such as sciencefiction, fantasy, horror, magical realism, and other speculative genres, Afrofuturism re-envisions the past, present, and future in order to show what the Black community does and can look like in imaginative and yet intensely real ways... Afrofuturism explore issues that also defy borders and definition, such as disability, sexuality, and gender (Grue, 2020, p. 33).
\end{abstract}

Afrofuturism can allow for the construction of alternative imaginaries, for example in practice by allowing differently socially situated communities to imagine "What would Facebook look like if it were designed by and for" Indigenous Americans [...] or descendants of the African diaspora?" (Grue, 2020, p. 39). In addition, decolonial audiovisual literacy projects provide important groundwork. For example, at the University of Veracruz (Mexico), students participating in the Sound Film Grammar class form a community of practice to develop "decolonial audiovisual literacy" as a "political-pedagogical project", over the course of the program participants are motivated to develop alternative anti-racist "gazes to offer resistance to the coloniality of seeing" (Moedano, Hernández Vasquez, Méndez-Tello, 2019, p. 206). Decolonizing media literacy revolves around making visible the politics of representation in reproducing privilege and disadvantage in for example "the symbolic construction of "indigenous", "spaniards", "blacks" and "mestizos"; while it recognized and empowered subjects in diversity" (Moedano, 2018, p. 201).

Alongside thinking about structural inequalities that prevent marginalised groups from being represented in the public sphere and creating opportunities for self-representation of these groups, we also need to consider the question: who is listening (Levine, 2008)? No structural change can come about without majority groups becoming receptive to attend to those demands. Looking at community media interventions that focus on giving voice to marginalised communities, Tanja Dreher reminds us that speaking up does not guarantee being heard, but rather depends on being 'granted an audience' (2010, p. 99). Susan Bickford (1996) mainly focuses on politics of listening and argues that not listening is an active exercise of power by the privileged in the society $(1996$, p. 3). Listening requires the listener to quiet their inner voice and leave themselves open to persuasion and it opens up a possibility for learning and connection (Bickford, 1996 cit. in Dreher, 2010, p. 100). Challenging the concentration of media power and developing an inclusive approach to media literacy education requires the consideration of the politics and power of listening and hearing (Dreher, 2010, p. 101) as well as the audiences of media products, which emerge out of media literacy projects (Levine, 2008).

Taking the considerations above as a starting point, we would like to propose four principles to work towards a more systematic approach to critical media literacy education. Firstly, inclusive media literacy should address not only migrants, refugees, minorities, LGBTQs, disabled people and other suppressed groups, but the entire society: diversity is not only a responsibility or burden of minorities, migrants and refugees. Secondly, media literacy education should build people's critical thinking skills about the mediated constructions of reality challenging the dominant representations that are disseminated through media. Thirdly, media literacy education can also equip people with skills to raise their own voice and be represented with their own through media production and participation. Fourthly, media literacy education should include attempts to 
promote a culture of listening. It is not only a matter of giving voice to those who are under- or misrepresented and suppressed in and through dominant media structures, but also about who is listening and how. Beyond empowering those marginalised to speak up, there is a dire need for those in the centre to hear, both those who produce media and their imagined audiences. In today's societies divided not only by ethnic and socio-economic differences, but physical borders, walls or global pandemics, an inclusive media literacy education is necessary for building bridges of communication and understanding.

\section{Links to Digital Materials}

Diraya.media media activism and media litercy in the MENA region https://www.diraya.media/

GPS, by Mediaspro Gender ethics in journalism for media professionals http://gps.contactgps.ch/rungps/show\#

Media Education for Equity and Tolerance (MEET) Toolkit. https://meetolerance.eu/toolkit/

Mentor + Media iOS media literacy app for professionals working with refugee and migrant youth

Our Practice: Documenting community radio in India and its contribution to freedom of expression through a series of short videos made by the Community Radio Reporters: http://ideosyncmedia.org/Publications/Our_Practice_IPDC.pdf

Open Gender Tracking (https://opengendertracking.github.io/), tool developed at the Massachusetts Institute for Technology for computationally tracking gender in news content

Project Look Sharp https://projectlooksharp.org/front end.php?kit_id=7, a program of Ithaca College with lessons and kits for K-16 educators to enhance students' critical thinking, metacognition, and civic engagement through media literacy materials and professional development.

Speak Up! Media for inclusion http://irex-europe.fr/portfolio-item/speak-up-media-for-inclusion/

TedX Mohammed Bitar, migrant YouTuber "How to turn tragedy into comedy". YouTube https://www.youtube.com/watch?v=diNig56gd-g

\section{Further Reading}


Paper accepted to be published in S. Roy; F. Subervi and M. Georgiou (Eds.): The Oxford Encyclopedia of Race, Ethnicity and Communication. Oxford: Oxford University Press.

Christ, G. W. \& De Abreu, B. S. (2020). Media literacy in a disruptive media environment. Routledge: New York.

De Abreu, B. S. \& Mihailidis, P. (2014). Media literacy education in action. Theoretical and pedagogical perspectives. Routledge: New York.

Liou, A., \& Literat, I. (2020). "We Need You to Listen to Us": Youth Activist Perspectives on Intergenerational Dynamics and Adult Solidarity in Youth Movements. International Journal of Communication, 14(21), 4662-4682.

Literat, I., Kligler-Vilenchik, N., Brough, M., \& Blum-Ross, A. (2018). Analyzing youth digital participation: Aims, actors, contexts and intensities, The Information Society, 34(4), 261-273.

Niesyto, H., Buckingham, D., \& Fisherkeller, J. (2003). Video culture: Crossing borders with young people's video productions. Television \& New Media, 4(4), 461-482.

Tisdell, E. J. \& Thompson, P. M. (2007). "Seeing from a different angle": the role of culture in teaching for diversity and critical media literacy in adult education. International Journal of Lifelong Education, 26(6): 651-673.

Ramasubramanian, S., \& Darzabi, R.C. (2020). Civic engagement, social justice, and media literacy. In Christ, W., \& Abreu, B., (Eds.), Media literacy in a disruptive media environment, (pp. 2-20)

Oxon:

Routledge.

Vasudevan, L., Kerr, K.R., Hibbert, M., Fernandez, E., \& Park, A. (2014). Cosmopolitan literacies of belonging in an after-school program with court-involved youths. Journal of Adolescent \& Adult Literacy, 57(7), 538-548.

\section{References}

Aufderheide, P. (1992). Aspen Media Literacy Conference Report. CML Center for Media Literacy._Retrieved from: http://www.medialit.org/reading-room/aspen-media-literacyconference-report-part-ii

Beilin, I. (2015). Beyond the threshold: Conformity, resistance, and the ACRL Information Literacy Framework for Higher Education. In the Library with the Lead Pipe. Retrieved from http:/www.inthelibrarywiththeleadpipe.org/2015/beyond-the-threshold-conformityresistance-and-the-aclr-information-literacy-framework-for-higher-education/

Bozdağ, Ç. (2018). Intercultural learning in schools through telecollaboration? A critical case study of eTwinning between Turkey and Germany. International Communication Gazette, $80(7), 677-694$. 
Paper accepted to be published in S. Roy; F. Subervi and M. Georgiou (Eds.): The Oxford Encyclopedia of Race, Ethnicity and Communication. Oxford: Oxford University Press.

Bozdağ, Ç. (2020). Bottom-up nationalism and discrimination on social media: An analysis of the citizenship debate about refugees in Turkey. European Journal of Cultural Studies, 23(5), $712-730$.

Bickford, S. (1996). The dissonance of democracy: Listening, conflict, and citizenship. Ithaca, NY: Cornell University Press.

Breivik, P. S., Hancock, V., and J.A. Senn (1998). A progress report on information literacy: an update on the American Library Association Presidential Committee on Information Literacy: Final report. ACRL: Chicago. Retrieved from: http://www.ala.org/acrl/publications/whitepapers/progressreport

Bruinenberg, H., Sprenger, S., Omerović, E., \& Leurs, K. (2019). Practicing critical media literacy education with/for young migrants: Lessons learned from a participatory action research project. International Communication Gazette, 83(1), 26-47. https://doi.org/10.1177/1748048519883511

Chakravartty, P., Kuo, R., Grubbs, V., \& McIlwain, C. (2018). \#CommunicationSoWhite, Journal of Communication, 68(2) 254-266.

Chapman, M. (2016). Mapping of media literacy practices and action in EU-28. Strasbourg: European Audiovisual Observatory for the European Commission. Retrieved from: https://ec.europa.eu/digital-single-market/en/news/reporting-media-literacy-europe.

Buckingham, D. (2009). The future of media literacy in the digital age: some challenges for policy and practice. Euromeduc. Media literacy in Europe. Controversies, Challenges and Perspectives. Retrieved from: http://www.euromeduc.eu/IMG/pdf/Euromeduc_ENG.pd

Buckingham, D. (2006). Defining digital literacy - What do young people need to know about digital media? Nordic Journal of Digital Literacy, 4(1), 263-276.

Bundy, A. (2004). One essential direction: information literacy, information technology fluency. Journal of Literacy, 1(1), 7-22.

CHICAM (2005). Final Report. Children in Communication About Migration. Retrieved from: https://cordis.europa.eu/project/id/HPSE-CT-2001-00048/reporting

Cooper, C. (2010). Fat Studies: Mapping the Field. Sociology Compass, 4, 1020-1034.

Costanza-Chock, S. (2018). Media, communication, and intersectional analysis: ten comments for the International Panel on Social Progress. Global Media and Communication, 14(2), 201209.

CRC (2021). General Comment No. 25. Children's rights in relation to the digital environment. United Nations, retrieved from https://tbinternet.ohchr.org/layouts/15/treatybodyexternal/Download.aspx?symbolno $=\mathrm{C}$ $\underline{\mathrm{RC} \% 2 \mathrm{fC} \% 2 \mathrm{fGC} \% 2 \mathrm{f} 25 \& \mathrm{Lang}=\mathrm{en}}$

Crenshaw, K. (1989). Demarginalizing the intersection of race and sex. University of Chicago Legal Forum, 139-167.

Directive 2007/65/Ec of The European Parliament and of The Council of 11 December $2007 . \quad$ Retrieved from https://eur-

lex.europa.eu/LexUriServ/LexUriServ.do?uri=OJ:L:2007:332:0027:0045:EN:PDF. 
Paper accepted to be published in S. Roy; F. Subervi and M. Georgiou (Eds.): The Oxford Encyclopedia of Race, Ethnicity and Communication. Oxford: Oxford University Press.

Dahya, N. (2017). Critical perspectives on youth digital media production: 'voice' and representation in educational contexts, Learning, Media and Technology, 42(1), 100-111.

Dreher, T. (2010). Speaking up or being heard? Community media interventions and the politics of listening. Media, Culture \& Society, 32(1), 85-103.

Dussel, I., \& Dahya, N. (2017). Introduction: problematizing voice and representation in youth media production, Learning, Media and Technology, 42(1), 1-7.

DW. (2019). Connect the unconnected! Deutsche Welle. Retrieved from https://www.dw.com/en/connect-the-unconnected/a-47168799.

European Commission (n.d.). Media literacy. https://ec.europa.eu/digital-single-market/en/medialiteracy.

Friesem, Y. (2017). Beyond accessibility: How media literacy education addresses issues of disabilities. Journal of Media Literacy Education, 9(2), 1-16.

Friesem, E., \& Friesem, Y. (2019). Media literacy education in the era of post-truth: Paradigm crisis. In M. Yildiz, M. Fazal, M. Ahn, R. Feirsen, \& S. Ozdemir (Eds.), Handbook of research on media literacy research and applications across disciplines (pp. 119-134). Hershey, PA: IGI Global

Funk, S. S. (2018). A trans*+ media literacy framework for navigating the dynamically shifting terrain of gender in media: Considering assessment of key competencies. In M. N. Yildiz, S.S. Funk \& B. S. De Abreu (Eds.), Promoting global competencies through media literacy (pp. 216-239). Hershey, PA: IGI Global.

Gauntlett, D. (2018, August 18). Media Studies 2.0. Retrieved form: https://davidgauntlett.com/digital-media/from-the-archives-media-studies-2-0/

Georgiou, M. (2018) Does the subaltern speak? Migrant voices in digital Europe, Popular Communication, 16:1, 45-57.

Gilster, P. (1997). Digital literacy. New York: Wiley.

Grue, M.N.P. (2020). An afrofuturistic vehicle for literacy instruction. Journal of College Reading and Learning, 50(1), 33-44.

Jacquinot-Delaunay, G., Carlsson, U., Tayie, S., \& Perez Tornero, J. M. (2008). Empowerment through media education. An intercultural approach. In U. Carlsson, S. Tayie, G. JacquinotDelaunay \& J. M. Perez Tornero (Eds.), Empowerment through media education. An intercultural dialogue. (pp. 19-37). Göteborg: Nordicom.

Kalmus, V., Pruulmann-Vengerfeldt, P., Runnel, P. and Siibak, A. (2009). Mapping the terrain of 'Generation C': Places and practices of online content creation Estonian teenagers. Journal of Computer-Mediated Communication, 14(4), 1257-1282.

Kellner, D. (1998). Multiple literacies and critical pedagogy in a multicultural society. Educational Theory, 48(1), 103-122. 
Paper accepted to be published in S. Roy; F. Subervi and M. Georgiou (Eds.): The Oxford

Encyclopedia of Race, Ethnicity and Communication. Oxford: Oxford University Press.

Kellner, D. and Share, J. (2007). Critical media literacy is not an option. Learning Inquiry, 1(1), 59-69.

Koltay, T. (2011). The media and the literacies: media literacy, information literacy, digital literacy. Media, Culture \& Society, 33(2), 211-221.

Lee, A. Y. L. (2021). The development of media literacy in Chinese societies: From grassroots efforts to institutional support. In D. Frau-Meigs et al. (eds) The handbook of media education research (pp. 309-325). Hoboken, NJ: John Wiley \& Sons.

Levine, P. (2008). A public voice for youth: The audience problem in digital media and civic education. In W. L. Bennett. (ed). Civic Life Online: Learning How Digital Media Can Engage Youth (pp. 119-138). Cambridge, MA: The MIT Press.

Livingstone, S. (2004). Media literacy and the challenge of new information and communication technologies. The Communication Review, 7(1), 3-14.

Livingstone, S., Van Couvering, N., \& Thumim, N. (2008). Converging traditions of research on media and information literacies. In J. Coiro, M. Knobel, C. Lankshear \& D. J. Leu (Eds.), Handbook of research on new literacies (pp. 103-131). New York, NY: Routledge.

Martin, L.E.M. (Ed.) (1997). The challenge of internet literacy: the instruction-web convergence. Philadelphia, PA: Haworth Press.

Matsuda, M.J. (1991). Beside my sister, facing the enemy: Legal theory out of coalition.Stanford Law Review, 43(6), 1183-1192.

McLaughlin, K. (2016). Empowerment: A critique. Oxon: Routledge.

McClure, C.R. (1994). Network literacy: a role for libraries? Information Technology and Libraries, 13(2), 115-125.

MILEN (2020). MIL for the underserved - Ideosync media combine. Media and Information Literacy Expert Network. Retrieved from: https://milenexpertnetwork.wordpress.com/2020/06/02/mil-for-the-underservedideosync-media-combine/

Melki, J. (2018). Guest editorial: Towards a media literacy of the oppressed. Media Education Research Journal, 8(1), 5-13.

Mihailidis, P. (2018). Civic media literacies: re-imagining engagement for civic intentionality. Learning, Media and Technology, 43(2), 152-164.

Moedano, RZ., Hernández Vasquez, A. \& Méndez-Tello, K.M. (2019), Educar miradas en resistencia a la colonialidad del ver. Contratexto 32, 205-228.

Moedano, R.Z. (2018). Alfabetización mediática decolonial para la formación de miradas antirracistas en la universidad. Revista Ra Ximhai, 14(2), 201-224.

Musarò, P. (2019). Aware Migrants: The role of information campaigns in the management of migration. European Journal of Communication, 34(6), 629-640. 
Paper accepted to be published in S. Roy; F. Subervi and M. Georgiou (Eds.): The Oxford Encyclopedia of Race, Ethnicity and Communication. Oxford: Oxford University Press.

Nikunen, K. (2019) Once a refugee: selfie activism, visualized citizenship and the space of appearance, Popular Communication, 17(2), 154-170.

Noble, S.U. \& Tynes, B.N. (2016). Introduction. In S.U. Noble \& B.M. Tynes (Eds.), The Intersectional Internet (pp. 1-20). New York, NY: Peter Lang.

O'Dowd, R., \& Lewis, T. (Eds.). (2016). Online intercultural exchange: Policy, pedagogy, practice. New York: Routledge.

Ofcom, (2006). Media Literacy Audit. Retrieved from:_https://www.ofcom.org.uk/research-anddata/media-literacy-research/adults/medialit_audit

Pangrazio, L. \& Sefton-Green, J. (2020). The social utility of 'data literacy'. Learning, Media and Technology, 45(2), 208-220.

Plester, B. and Wood, C. (2009). Exploring relationships between traditional and new media literacies: British preteen texters at school. Journal of Computer-Mediated Communication, 14(4), 1108-1129.

Pool, C. R. (1997). A new digital literacy: A conversation with Paul Gilster. Educational Leadership. Retrieved from: http://www.ascd.org/publications/educationalleadership/nov97/vol55/num03/A-New-Digital-Literacy@-A-Conversation-with-PaulGilster.aspx

Raineri, M. (2019). Introduction. In: M. Ranieri (ed.) Media Education for Equity and Tolerance. Theory, policy, and practices (pp. 9-18). Rome: Aracne editrice.

Rooks, Matthew (2008). A unique opportunity for communication: An intercultural email exchange between Japanese and Thai students. Call EJ Online 10(1), retrieved from: http://callej.org/journal/10-1/rooks.html

Siapera, E., Boudourides, M., Lenis, S., \& Suiter, J. (2018). Refugees and network publics on Twitter: Networked framing, affect, and capture. Social Media+ Society, 4(1), 2056305118764437.

Simões, R. B., Amaral, I., \& Santos, S. C. (2020). Media education and digital inclusion: Tackling the social exlusion of disadvantaged grous in Europe. In C. L. Gómez, A. López Martínez, \& I. Candel Torres (Eds.), Proceedings of INTED 2020 Conference 2nd-4th March 2020 (pp. 6527-6534). Valencia: IATED.

Subervi-Vélez, F. \& Cantrell Rosas-Moreno, Tania (2020). The imperative for Latino-oriented media \& news literacy. In W. G. Christ \& B. S. De Abreu (Eds.), Media literacy in a disruptive media environment (pp. 109-119). NY: Routledge.

Titley, G. (2020). Is free speech racist? Oxford: Polity.

UNESCO, n.d. About Media and Education Literacy. United Nations Alliance on of Civilizations. Retrieved from: http://milunesco.unaoc.org/about-media-and-education-literacy

UNESCO, 2013. Global Media and Information Literacy Assessment Framework: Country Readiness and Competencies. Retrieved from: http://unesdoc.unesco.org/images/0022/002246/224655e.pdf 
Paper accepted to be published in S. Roy; F. Subervi and M. Georgiou (Eds.): The Oxford Encyclopedia of Race, Ethnicity and Communication. Oxford: Oxford University Press.

Wall, M., Janbek, D., \& Campbell, M.O (2019). Syrian refugees and information precarity. New Media \& Society, 19(2), 240-254.

Warschauer, M. (2001). Millenialism and media: language, literacy, and technology in the 21st century. In D. Graddol, (Ed.), Applied linguistics for the 21st century. Milton Keynes: International Association of Applied Linguistic.

Waheed Khan, A. (2008). Media education, a crucial issue in the building of an inclusive knowledge society. In U. Carllson et al. (Eds.), Empowerment through Media Education, An Intercultural Dialogue, (pp. 15-18). Göteborg: Nordicom.

Wilson, C., Grizzle, A., Tuazon, R., Akyempong, K., \& Cheung, C. K. (2014). Media and information literacy curriculum for teachers. Paris: UNESCO Publishing.

Van Gorp, B. (2005). Where is the frame? Victims and intruders in the Belgian press coverage of the asylum issue. European Journal of Communication, 20(4), 484-507.

Yosso, T. J. (2002). Critical Race Media Literacy: Challenging Deficit Discourse about Chicanas/os. Journal of Popular Film and Television, 30(1), 52-62.

Zaborowski, R., \& Georgiou, M. (2016, November 17). Refugee "crisis”? Try "crisis in the European press”. Open Democracy. Retrieved from: https:/www.opendemocracy.net/ rafal-zaborowski-myria-georgiou/refugee-crisis-try-crisis-in-european-press.

Zezulkova, M. \& Neag, A. (2019). Wishful thinking and real outcomes: Teaching media literacy to marginalised children. Media Education Research Journal, 9(1), 5-10.

Zurkowski, P. (1974). The information service environment: Relationships and Priorities. Related paper no.5. Washington, DC: National Commission on Libraries and Information Science.

\footnotetext{
${ }^{1}$ https://europeanjournalists.org/past-projects-2/media-against-hate/

2 https://mediasmarts.ca/tutorial/facing-online-hate-tutorial

3 https://meetolerance.eu/toolkit/

4 https:/www.etwinning.net/en/pub/index.htm

5 https://threedollarbillcinema.org/

6 https://cordis.europa.eu/project/id/HPSE-CT-2001-00048

${ }^{7}$ http://irex-europe.fr/portfolio-item/speak-up-media-for-inclusion/

${ }^{8} \mathrm{https}$ ://ec.europa.eu/digital-single-market/en/news/2018-2019-call-proposals-preparatory-action-media-literacy-all

${ }^{9}$ https://www.cyberwise.org/in-spanish

${ }^{10} \mathrm{http}: / /$ www.ideosyncmedia.org/

11 https://www.defindia.org/

12 https://rising.globalvoices.org/

${ }_{13} \mathrm{https}: / / w w w . d i r a y a . m e d i a / a b o u t-u s /$

14 http://www.pyalara.org/\#

15 https://ccimcambodia.org/
} 